Article

\title{
The Probability of an Unrecoverable Coral Community in Dongsha Atoll Marine National Park Due to Recurrent Disturbances
}

\author{
Yu-Rong Cheng *, Chi-Hsiang Chin, Ding-Fa Lin and Chao-Kang Wang \\ Department of Fisheries Production and Management, National Kaohsiung University of Science and \\ Technology, Kaohsiung 81157, Taiwan; swimmer1980@gmail.com (C.-H.C.); \\ love1001green5209@gmail.com (D.-F.L.); stevn0665566@yahoo.com.tw (C.-K.W.) \\ * Correspondence: yrcheng@nkust.edu.tw; Tel.: +886-7-361-7141 (ext. 23506)
}

Received: 26 September 2020; Accepted: 29 October 2020; Published: 30 October 2020

\begin{abstract}
In recent decades, coral reefs worldwide have been impacted annually by climate change and anthropogenic impacts. Marine parks are utilized to protect coral reef ecosystems and to ensure it is in sustainable use. In the present study, a 15-year change in coverage and composition of a hard coral community at Dongsha Atoll Marine National Park (DAMNP) was examined from 2005 to 2019. The reef has experienced several disturbances, including 11 typhoons and six coral bleaching events. A $34.39 \%$ decline in coral coverage had been recorded over the past 15 years in response to multiple and recurrent natural disturbances. The coral communities and functional ecology of the Dongsha Atoll changed during this period. The average dissimilarities in coral communities ranged from 55.38 to $59.02 \%$. The dramatic decrease in the abundance of branching corals in addition to a slight increase in massive and encrusting corals suggest the habitat has simplified. The degraded coral reef communities represent a low resilience ecosystem, even though the DAMNP has been established. Without effective management, the coral reef ecosystem of the Dongsha Atoll may not persist due to repeated impacts from recurrent disturbances.
\end{abstract}

Keywords: marine park; coral community; Dongsha Atoll; climate change

\section{Introduction}

Coral reefs, the tropical rainforests of the sea, are one of the most productive ecosystems on Earth, providing important services to fisheries, coastal protection, medicines, and tourism [1]. However, the numbers of annual disturbances (typhoons, flood plumes, and climate change) and anthropogenic impacts (overfishing, pollution, sedimentation, and coastal development) on reefs have increased rapidly in recent decades, causing strains on coral reefs around the world [2-5]. It was predicted that most coral reef ecosystems will suffer from severe bleaching events every year, and the impact level will exceed the extent of the 1998 bleaching event by the year 2040 [2]. It is estimated that $15 \%$ of the worldwide coral reefs are already severely degraded and the remainder, approximately $20 \%$ of the world's coral reefs, will be under threat of loss within the next 20 to 40 years if there is no effective solution [5]. Therefore, it appears these degraded coral reef ecosystems suffered from escalating pressures at a global scale, which have led to an intense discussion on the strategies to conserve the biodiversity, enhance the resilience, and maintain the ecosystem processes in these habitats $[3,4,6,7]$.

Marine Protected Areas (MPAs) are a section of the ocean where a government has placed limits on human activities. A Marine Park (MP), or a Nation Park (NP), is a type of MPA, meaning they include zoning plans to permit various human activities [8,9]. It is sometimes protected for recreational use, but is usually a set-aside for conservation $[8,9]$. Establishing an effective MP is a practical approach, 
with consensus from conservation biologists, to better manage and conserve marine systems and coral reef ecosystems [6,8-13]. Even though there are extensive research evidence that proves the benefits of using an MP to manage and conserve marine biodiversity, some failure examples from mitigating the natural and anthropogenic disturbances have caused extensive debates on its effectiveness [8,9,14-18].

A well-developed coral reef structure across a multi-dimensional space and with a high coral coverage was found in the Dongsha Atoll (DA). With rich fishery resources, it has traditionally been recognized as an important fishing ground for many countries, such as China, Hong Kong, Taiwan, and Vietnam [19]. It has been the major reef in the northern South China Sea, thus playing an important role in the main breeding and nursery grounds for numerous marine organisms $[19,20]$. In 2007, the government of Taiwan designated it as a marine national park (hereafter, DAMNP) based on the concerns for sustainable fisheries management and to mitigate the effects of potential environmental impacts. Until now, it is still a protected area and is yet to be opened to tourists. However, despite having established the DAMNP, the Dongsha reef has suffered from natural and anthropogenic disturbances, including typhoons [21], coral bleaching events [22-24], illegal fishing (poisons and explosives) and overfishing [25-27], the proliferation of macroalgae [28], outbreaks of the coral predator Acanthaster planci Linnaeus 1758 (crown-of-thorns starfish) [29], and coral diseases or parasites [30]. These disturbances have continued to degrade the coral-dominated assemblages in the DAMNP waters. The reason behind the challenge in establishing a more appropriate and effective management for the DA is the current lack of understanding the changes in coral communities from disturbances.

In the present study, changes in coral coverage and composition at DAMNP were analyzed based on the surveys conducted from 2005 to 2019. We were particularly interested in whether recurrent disturbances played a major role in the state of coral communities (coral coverage, biodiversity, species composition, and ecological functions), especially in three different periods: before DAMNP establishment (in 2006), the period of the following five years (2006 to 2012), and the period of the following twelve years (2006 to 2019).

\section{Materials and Methods}

\subsection{Study Site}

Dongsha Atoll (DA) is located at $20^{\circ} 40^{\prime} 43^{\prime \prime} \mathrm{N}$ and $116^{\circ} 42^{\prime} 54^{\prime \prime} \mathrm{E}$, and is the largest and the first developed, northernmost atoll in the South China Sea (SCS). It has formed a perfect ring-shaped reef with well-developed coral reefs, supporting highly diverse fauna and flora. It is about $340 \mathrm{~km}$ southeast of Hong Kong, $260 \mathrm{~km}$ south of Shantou off the Chinese mainland, and $450 \mathrm{~km}$ southwest of Taiwan (Figure 1). The atoll is approximately $25 \mathrm{~km}$ wide in diameter, and its reef table that emerges above water during low tides is approximately $46 \mathrm{~km}$ in length and $2 \mathrm{~km}$ in width. The inner-reef and lagoon covers more than $600 \mathrm{~km}^{2}$, and the maximum depth is approximately $23.7 \mathrm{~m}[19,20]$.

\subsection{The Historical State of the Dongsha Atoll (DA) Coral Community}

\subsubsection{Species Diversity of the Corals}

Based on the results from extensive biological surveys conducted from 1975 to 2019, a total of 384 species of Cnidaria has been recorded in DA, including 257 species in 56 genera of the Scleractinia family, 118 species in 30 genera of the Alcyonacea family, two species in two genera of Antipatharia family, one species in one genus of Helioporacea family, and six species in two genera of Anthoathecata family (Figure 2). 


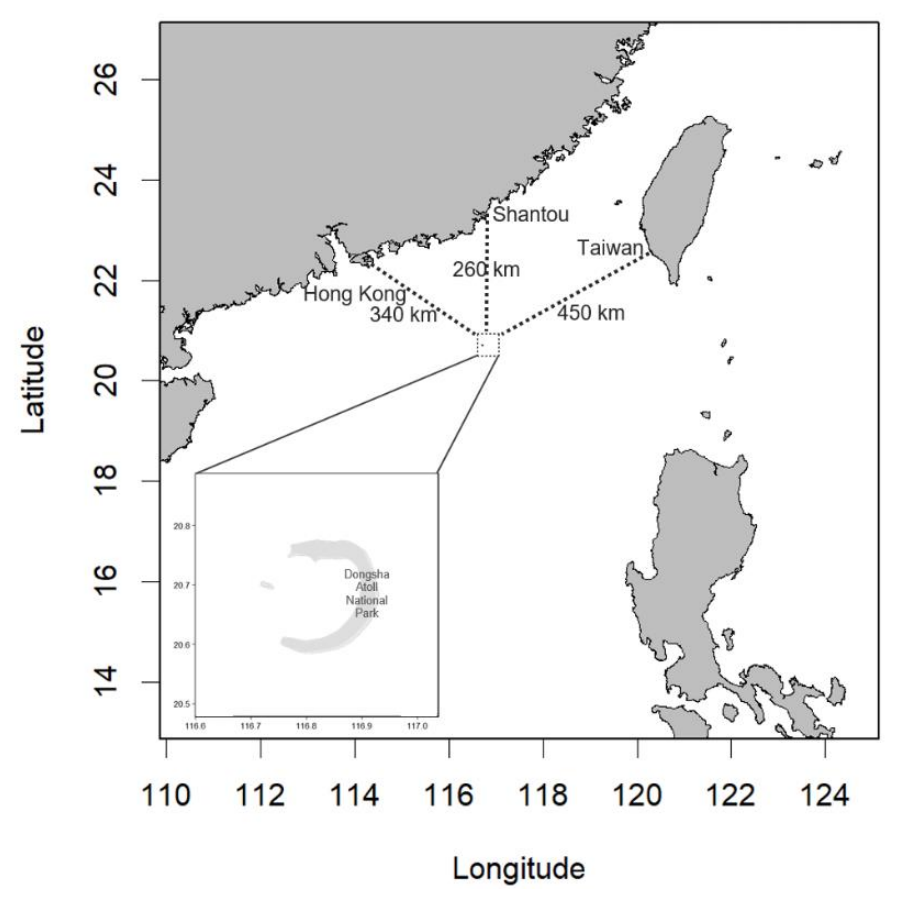

Figure 1. Map of Dongsha Atoll in the northern South China Sea.

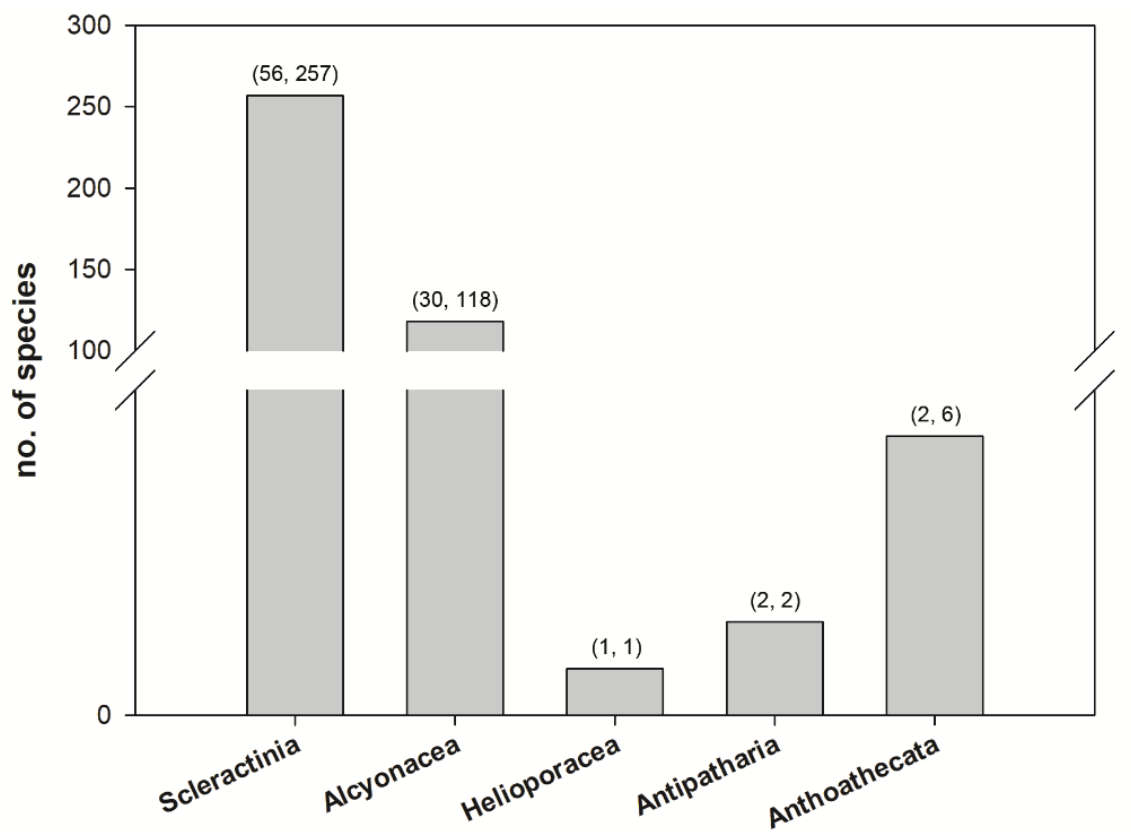

Figure 2. A total of 384 species of Cnidaria has been recorded by extensive biological surveys conducted from 1975 to 2019 in the Dongsha Atoll (DA). The numbers in the parentheses indicate the number of genera and species.

\subsubsection{Coral Communities Prior to 1998: Before the Severe Coral Bleaching Event}

The coral fauna in the DA has a close affinity with those from the Indo-West Pacific province, southern Taiwan, and Taiping Island [19]. According to Dai et al. [21], a high biodiversity (a total of 137 coral species) was recorded, and there was approximately over $50 \%$ of the average coral coverage (higher than $80 \%$ in some locations). At that time, well-developed coral communities occurred both in the outer and inner reefs. The coral communities were dominated by scleractinians, and Acropora spp. and Porites spp. were the most abundant and widespread corals in Dongsha $[19,21,31,32]$. 
2.2.3. Coral Communities from 1998-2007: Prior to the Establishment of Dongsha Atoll Marine National Park (DAMNP)

After the exceptional high seawater surface temperatures and a severe coral bleaching event observed in 1998, a significant decline in the coral coverage and biodiversity occurred from several biological surveys [22-24]. The live coral coverage (LCC) ranged from $<1$ to $6 \%$ and roughly around $23 \%$ in the outer reef and lagoon, respectively. In total, over $90 \%$ of the reefs and inhabitants were killed and replaced by filamentous algae or macroalgae [19]. Moreover, a dramatic degradation of coral reefs might be also caused by overfishing and destructive fishing practices, such as the overuse of poisons and explosions from illegal fishing, resulting in a dramatic decline in the coral species richness to the point that $60-90 \%$ of the corals died $[25,26]$. In terms of species composition of scleractinians, the coral species belonging to the Merulinidae and Fungiidae were dominant and the foliaceous corals (Echinopora gemmacea, Echinopora lamellose, and Echinopora aspera) were abundant in the inner reef $[19,33]$.

\subsubsection{Coral Communities from 2007-2012: The Protected Period}

Field surveys conducted in 2012 revealed that the highest coral coverage (about 80\%) was recorded from the outer reef, while the LCC of the inner reef was highly variable, ranging from $10.5 \%$ to $71.5 \%$ [34]. During the study period, no mass coral bleaching event occurred, but only a few individuals of Acanthaster planci were found. According to Gomez et al. [35] and Connell et al. [36], an LCC between 51 and $75 \%$ indicates a positive status. Thus, the coral coverage at most sites was higher than $50 \%$ in 2012, indicating that the reef environment was suitable for coral growth. However, the study pointed out that the DAMNP was under the threat of high fishing pressure in 2012 since the number and size of fishes and benthic invertebrates were low, particularly for the commercial ones [34].

\subsection{Statistical Analysis}

The data of the ecological surveys on the temporal variation of coral coverage (hard and soft corals) from previous studies were conducted using the Reef Check protocol from 2005 to 2017 [28,33,34,37-42]. In this study, coral coverage and communities of DA were re-surveyed in 2019 to reveal its recent state. A hierarchical survey design that included different sectors (the outer reef and the inner reef/lagoon) and sites were applied. Each sector included several sites where the water depth was approximately $10 \mathrm{~m}$ (Appendix A). In order to reveal the change in hard coral community structures, we analyzed the field survey data conducted before the establishment of the DAMNP in 2006, 5 years later in 2012, and 12 years later in 2019 (see Appendix A for details). During this 15-year study, eleven major typhoons and six coral bleaching events (Appendix B and Figure 3) affected the DA. Variations in the diversity indices were calculated with a multivariate analysis package (Primer 6.0) [43]. A non-metric multidimensional scaling (nMDS) ordination of the coral communities was conducted to reveal the grouping of the surveyed sites. Analysis of similarity (ANOSIM) was applied to separate different groupings from the nMDS and the Similarity Percentage (SIMPER) analysis was used to reveal the species that contributed to $>90 \%$ of cumulative similarities within groups using a multivariate analysis package (Primer 6.0) [43]. In order to know whether the ecological functions of the coral community have been changed during this period, five coral growth forms (branching, encrusting, massive, foliaceous, and others) were referred to various functional groups. The structural variations of the functional groups among the sampling periods were explored using a principal components analysis (PCA, Primer 6.0). 


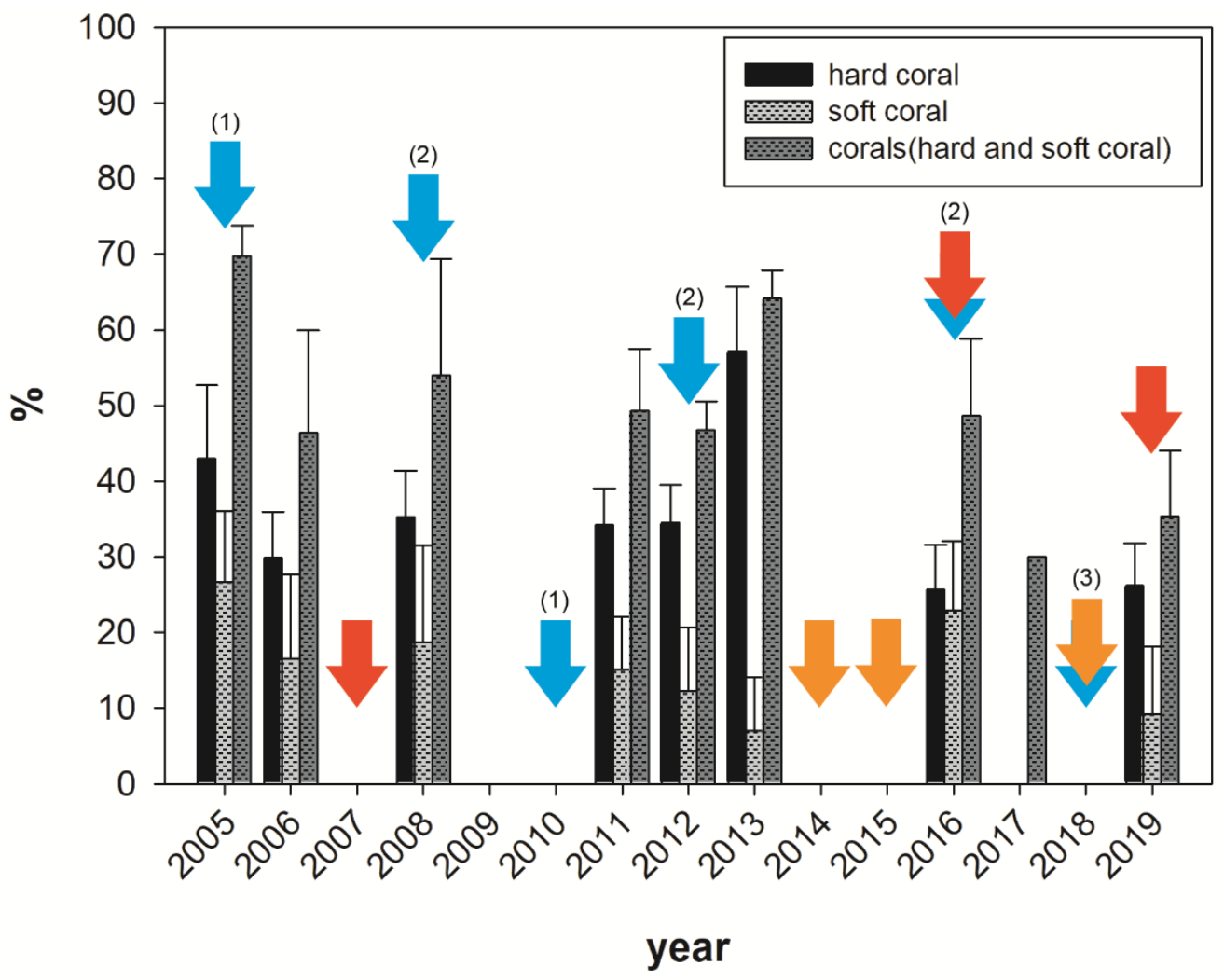

Figure 3. Temporal dynamics of the corals (hard and soft corals) in the Dongsha Atoll from 2005 to 2019. Eleven typhoons (blue color) and six bleaching events (orange: level 1; red: level 2) occurred in this period. The number in the parentheses indicates the number of typhoons.

\section{Results}

In 2019, a total of 257 species of scleractinian corals were recorded in the Dongsha Atoll (DA), and the top 20 species in abundance and five functional groups are listed in Table 1. The live coral coverage (LCC) dropped by $34.39 \%$, ranging from $69.75 \%$ (hard corals: $43.00 \%$; soft corals: $26.78 \%$ ) in 2005 to $35.39 \%$ (hard corals: 26.23\%; soft corals: 9.16\%) in 2019 (Figure 3). The diversity indices of the coral communities at the surveyed sites are shown in Table 2 . The highest species number $(115 \pm 15$ and $139 \pm 7$ ), colony number (463 \pm 67 and $508 \pm 51)$, Shannon diversity index (6.36 \pm 0.20 and $6.82 \pm 0.07)$, and Evenness $(0.96 \pm 0.00)$ were recorded in 2006 and 2012, while those indices were the lowest in 2019.

The LCC of the DA has changed considerably over the 15-year period in response to multiple natural and anthropogenic disturbances. As in Figure 3, several changes can be identified and divided into several disturbance and inter-disturbance periods (also called the recovery period). In 2005, the LCC was about $69.75 \%$, but in 2006, typhoon DAMREY caused a major decline in both soft and hard coral coverage, resulting in a sharp reduction to $46.38 \%$. In 2007, a severe coral bleaching event occurred. Unfortunately, without an ecological survey, the conditions of the coral remain unknown. In 2008, two typhoons (named NURI and HAGUPIT) hit the DA, but the coral coverage was almost at the same level as that in 2006. From 2009 to 2013, only three typhoons hit, and they happened in 2010 (LIONROCK) and 2012 (TALIM and TEMBIN). It seems to have been a major recovery period for the DA corals, particularly the hard corals. The hard coral coverage (57.20\%) in 2013 recovered to its original states and even higher than the percentage (43.00\%) in 2005, although the soft corals might be removed by the typhoons. However, between 2014 and 2019, multiple disturbances, including five typhoons and several major bleaching events (both Level 1 and 2), led to a steady degradation of the coral assemblage. 
Table 1. The hard coral species (the top 20 species in abundance) and five functional groups of corals recorded from the Dongsha Atoll from 2006 to 2019.

\begin{tabular}{|c|c|c|c|c|c|}
\hline & & & 2006 & 2012 & 2019 \\
\hline Coral Family & Species Name & Growth Form & Average \pm SE & Average \pm SE & Average $\pm \mathrm{SE}$ \\
\hline \multirow[t]{2}{*}{ Acroporidae } & Montipora grisea & encrusting & $5.43 \pm 1.53$ & $2.00 \pm 0.00$ & $5.60 \pm 3.11$ \\
\hline & Montipora informis & encrusting & $10.43 \pm 1.56$ & $8.00 \pm 3.00$ & $9.20 \pm 2.94$ \\
\hline Agariciidae & Pavona varians & encrusting & $4.57 \pm 0.43$ & $2.00 \pm 0.00$ & $14.20 \pm 0.80$ \\
\hline Euphylliidae & Galaxea fascicularis & other & $7.57 \pm 1.21$ & $2.00 \pm 0.00$ & $6.80 \pm 1.80$ \\
\hline \multirow[t]{2}{*}{ Fungiidae } & Herpolitha limax & other & 2.00 & 0.00 & 0.00 \\
\hline & Leptastrea transversa & massive & $3.00 \pm 0.63$ & $3.50 \pm 1.50$ & $7.40 \pm 1.47$ \\
\hline \multirow[t]{9}{*}{ Meruliniidae } & Cyphastrea serailia & massive & $3.00 \pm 0.63$ & $3.50 \pm 1.50$ & $4.00 \pm 1.92$ \\
\hline & Dipsastraea pallida & massive & $5.00 \pm 0.00$ & $3.50 \pm 1.50$ & $9.80 \pm 1.20$ \\
\hline & Dipsastraea speciosa & massive & $7.57 \pm 1.21$ & $8.00 \pm 3.00$ & $6.20 \pm 1.20$ \\
\hline & Echinopora gemmacea & foliaceous & $2.86 \pm 0.55$ & 2.00 & $4.80 \pm 2.56$ \\
\hline & Echinopora lamellosa & foliaceous & $4.14 \pm 1.26$ & 5.00 & $3.80 \pm 0.73$ \\
\hline & Favites abdita & massive & $9.29 \pm 1.11$ & $8.00 \pm 3.00$ & $11.80 \pm 0.80$ \\
\hline & Favites halicora & massive & 5.00 & $6.50 \pm 4.50$ & $9.80 \pm 1.20$ \\
\hline & Goniastrea edwardsi & massive & $2.86 \pm 0.55$ & $8.00 \pm 3.00$ & $3.20 \pm 0.73$ \\
\hline & Goniastrea retiformis & massive & $2.43 \pm 0.43$ & $5.00 \pm 0.00$ & $10.60 \pm 1.60$ \\
\hline Pocilloporidae & Pocillopora verrucosa & branching & $12.00 \pm 1.81$ & $3.50 \pm 1.50$ & $8.00 \pm 1.90$ \\
\hline \multirow[t]{4}{*}{ Poritidae } & Porites cylindrica & branching & $6.00 \pm 2.65$ & 0.00 & 0.00 \\
\hline & Porites lichen & foliaceous & $7.14 \pm 1.42$ & $8.00 \pm 3.00$ & $6.20 \pm 1.20$ \\
\hline & Porites lobata & massive & $3.29 \pm 0.61$ & $8.00 \pm 3.00$ & $7.40 \pm 1.47$ \\
\hline & Porites lutea & massive & $3.71 \pm 0.61$ & $3.50 \pm 1.50$ & $5.60 \pm 1.47$ \\
\hline \multicolumn{6}{|c|}{ Five Major Functional Groups of Corals } \\
\hline & & branching & $103.44 \pm 24.87$ & $58.70 \pm 7.52$ & $59.07 \pm 7.52$ \\
\hline & & encrusting & $24.38 \pm 4.53$ & $33.50 \pm 2.20$ & $35.21 \pm 6.50$ \\
\hline & & foliaceous & $68.81 \pm 11.45$ & $83.90 \pm 14.28$ & $51.14 \pm 8.28$ \\
\hline & & massive & $161.00 \pm 18.74$ & $243.20 \pm 23.46$ & $203.29 \pm 16.49$ \\
\hline & & other & $32.69 \pm 9.96$ & $49.10 \pm 14.82$ & $40.43 \pm 11.49$ \\
\hline
\end{tabular}

Scientific names are in italics.

Our results showed that the hard coral coverage dropped by $16.77 \%$, declining from $43.00 \%$ in 2005 to $26.23 \%$ in 2019 (Figure 3). The reason behind the mass decline in hard coral coverage can be explained by the dramatic decrease in branching corals, which plunged from $103.44 \pm 24.87$ colonies in 2006 to $59.07 \pm 7.52$ in 2019. For example, from 2006 to 2019, Pocillopora verrucosa decreased to $33.33 \%$ (Table 1). A similar trend also occurred in other corals with foliaceous growth forms similarly sensitive to a high sea water temperature and the mechanical impacts brought by the typhoon disturbances. In contrast, the massive and encrusting corals only showed a slight variation in coverage and abundance (Table 1). Favites halicora and Goniastrea retiformis have increased significantly since 2006. Subsequently, Pavona varians, Dipsastraea pallida, and Favites abdita increased significantly after 2012. They remained the top five taxa in terms of abundance in 2019 and recently became the dominant species (Table 1).

The results of the non-metric multidimensional scaling (nMDS) did not show a clear grouping pattern at the surveyed sites between 2006, 2012, and 2019. However, the nMDS groupings among the outer- and inner-reef sectors showed a more site-oriented cluster (Figure 4). The results were also supported by the result from the analysis of similarity (ANOSIM), suggesting most sites among the different years $(p<0.01$; Global $\mathrm{R}=0.64)$ and sectors $(p<0.01$; Global $\mathrm{R}=0.49)$ were separated with significant differences. The results from the similarity percentage (SIMPER) showed that most of the abundant species contributed to more than $90 \%$ of the cumulative similarities and dissimilarities in 2006, 2012, and 2019 (only shows over 10\% in Tables 3 and 4). The average similarities of the coral species at the surveyed sites ranged from 50.11 to $61.97 \%$, while the average dissimilarities ranged from 55.38 to $59.02 \%$ (Tables 3 and 4). Among these coral species, Porites lobata (average abundance $=2.13-3.24$ colonies; contribution $=1.95-4.03 \%$ ) was the most abundant in the period of 
this study. Other common species, including Porites lutea (2.06-3.15 colonies; contribute $=1.81-4.01 \%$ ), Goniastrea retiformis ( 1.91 colonies; contribute $=2.04 \%)$, and Favites abdita $(2.48$ colonies; contribute $=1.36 \%$ ), were also dominant. Nevertheless, most are encrusting and massive corals with a slower growth rate and recovery ability, except for Montipora informis ( 2.09 colonies; contribution $=1.66 \%$ ).

Table 2. The biodiversity measures, including colony number $(\mathrm{N})$, species number $(\mathrm{S})$, Shannon diversity index $\left(\mathrm{H}^{\prime}\right)$, and Evenness (E) in the studied sites of Dongsha in 2006, 2012, and 2019.

\begin{tabular}{|c|c|c|c|c|}
\hline Locations (Year) & $\mathbf{N}$ & $\mathbf{S}$ & $\mathbf{H}^{\prime}$ & E \\
\hline 06-1 (2006) & 702 & 161 & 6.98 & 0.95 \\
\hline $06-2(2006)$ & 687 & 164 & 7.00 & 0.95 \\
\hline $06-3(2006)$ & 686 & 176 & 7.17 & 0.96 \\
\hline $06-4(2006)$ & 704 & 188 & 7.26 & 0.96 \\
\hline $06-5(2006)$ & 648 & 159 & 7.07 & 0.97 \\
\hline $06-6(2006)$ & 663 & 152 & 6.96 & 0.96 \\
\hline 06-7 (2006) & 342 & 81 & 5.92 & 0.93 \\
\hline 06-8 (2006) & 209 & 55 & 5.49 & 0.95 \\
\hline $06-9(2006)$ & 757 & 176 & 7.16 & 0.96 \\
\hline $06-10(2006)$ & 828 & 186 & 7.19 & 0.95 \\
\hline 06-11 (2006) & 221 & 56 & 5.50 & 0.95 \\
\hline $06-12(2006)$ & 378 & 73 & 5.88 & 0.95 \\
\hline $06-13(2006)$ & 133 & 38 & 4.95 & 0.94 \\
\hline $06-14(2006)$ & 192 & 51 & 5.44 & 0.96 \\
\hline 06-A (2006) & 162 & 81 & 6.34 & 1.00 \\
\hline 06-B (2006) & 88 & 44 & 5.46 & 1.00 \\
\hline Average \pm SE & $463 \pm 67$ & $115 \pm 15$ & $6.36 \pm 0.20$ & $0.96 \pm 0.00$ \\
\hline $12-01(2012)$ & 625 & 138 & 6.72 & 0.94 \\
\hline $12-04$ (2012) & 374 & 124 & 6.71 & 0.96 \\
\hline $12-05$ (2012) & 814 & 161 & 7.04 & 0.96 \\
\hline $12-08$ (2012) & 584 & 156 & 6.98 & 0.96 \\
\hline $12-11(2012)$ & 280 & 104 & 6.49 & 0.97 \\
\hline $12-12(2012)$ & 368 & 116 & 6.61 & 0.96 \\
\hline $12-16(2012)$ & 512 & 154 & 6.94 & 0.95 \\
\hline $12-17$ (2012) & 638 & 173 & 7.15 & 0.96 \\
\hline $12-20(2012)$ & 487 & 138 & 6.85 & 0.96 \\
\hline $12-23$ (2012) & 399 & 127 & 6.71 & 0.96 \\
\hline Average & $508 \pm 51$ & $139 \pm 7$ & $6.82 \pm 0.07$ & $0.96 \pm 0.00$ \\
\hline $12-1$ (2019) & 223 & 60 & 5.55 & 0.94 \\
\hline $12-4$ (2019) & 609 & 102 & 6.34 & 0.95 \\
\hline $12-5$ (2019) & 521 & 75 & 5.89 & 0.95 \\
\hline $12-8(2019)$ & 574 & 103 & 6.32 & 0.95 \\
\hline $12-11$ (2019) & 182 & 28 & 4.38 & 0.91 \\
\hline $12-12$ (2019) & 251 & 57 & 5.51 & 0.94 \\
\hline $12-16$ (2019) & 415 & 68 & 5.72 & 0.94 \\
\hline $12-17$ (2019) & 524 & 100 & 6.28 & 0.95 \\
\hline $12-20$ (2019) & 485 & 93 & 6.20 & 0.95 \\
\hline $12-23(2019)$ & 520 & 100 & 6.30 & 0.95 \\
\hline 19-01 (2019) & 683 & 114 & 6.51 & 0.95 \\
\hline 19-02 (2019) & 462 & 89 & 6.13 & 0.95 \\
\hline 19-03 (2019) & 536 & 101 & 6.32 & 0.95 \\
\hline 19-05 (2019) & 351 & 68 & 5.75 & 0.94 \\
\hline Average & $453 \pm 40$ & $83 \pm 6$ & $5.94 \pm 0.15$ & $0.94 \pm 0.00$ \\
\hline
\end{tabular}



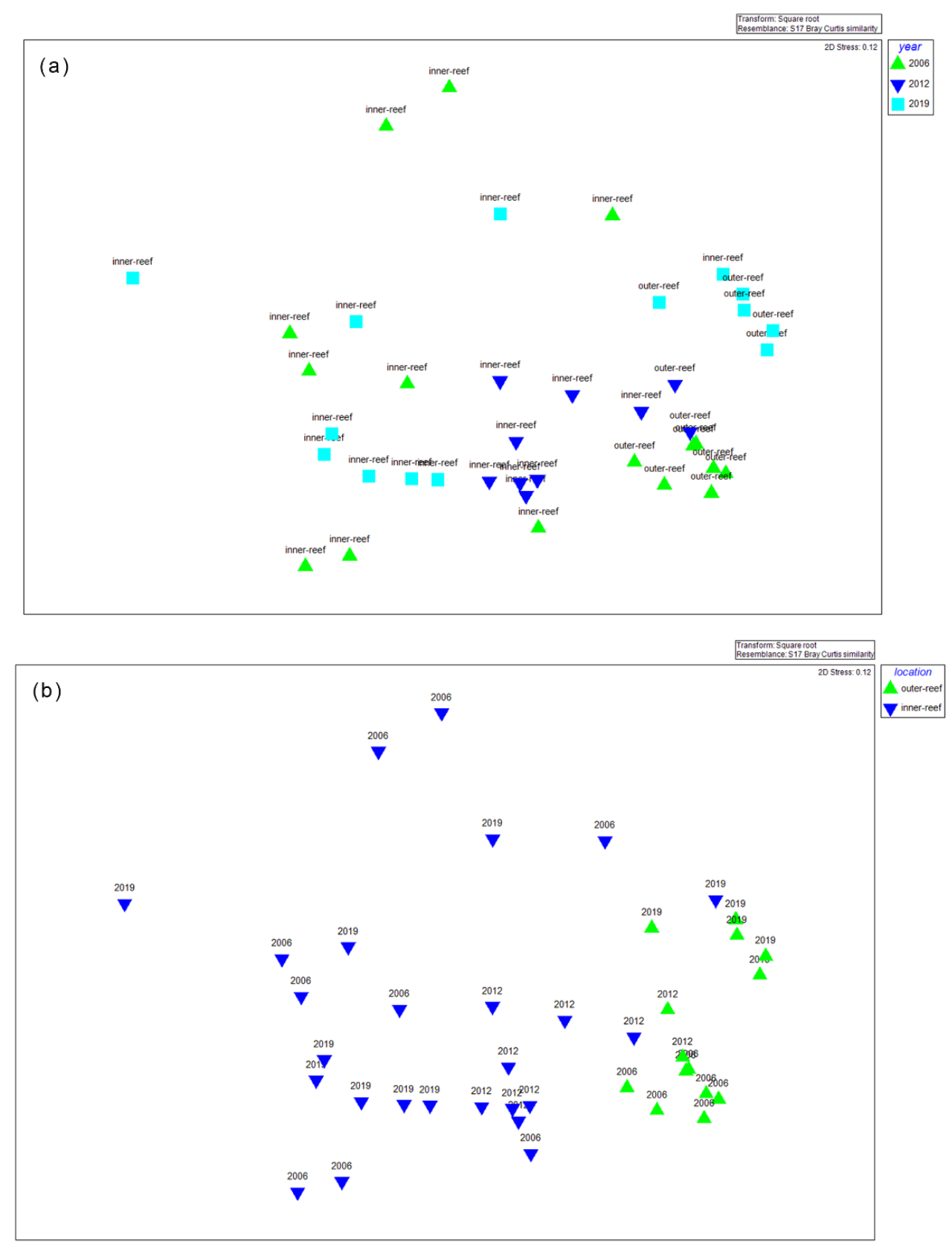

Figure 4. Multidimensional scaling (MDS) plot of the species composition and abundance of corals: (a) among various sampling periods (2006, 2012, and 2019); (b) among various locations (outer reef and inner reef).

Table 3. The average similarity of the coral species at the surveyed sites among 2006, 2012, and 2019. Only the corals with a more than $10 \%$ cum. contribution are listed.

\begin{tabular}{cccc}
\hline & Average Abundance & Contribution (\%) & Cum. Contribution (\%) \\
\hline Porites lobata & 2006 average similarity: 54.11 & \\
Porites lutea & 2.13 & 2.27 & 2.27 \\
Goniastrea retiformis & 2.06 & 2.16 & 4.43 \\
Goniopora djiboutiensis & 1.91 & 2.04 & 6.47 \\
Montipora informis & 1.96 & 1.80 & 8.27 \\
\hline
\end{tabular}


Table 3. Cont.

\begin{tabular}{cccc}
\hline & Average Abundance & Contribution (\%) & Cum. Contribution (\%) \\
\hline & 2012 average similarity: 61.97 & \\
\hline Porites lobata & 3.21 & 1.95 & 1.95 \\
Porites lutea & 2.86 & 1.81 & 3.77 \\
Favites abdita & 2.48 & 1.36 & 5.12 \\
Favites russelli & 2.29 & 1.32 & 6.44 \\
Astreopora ocellata & 2.21 & 1.31 & 7.75 \\
Turbinaria mesenterina & 2.23 & 1.25 & \\
\hline & 2019 average similarity: 50.11 & 4.00 \\
\hline Porites lobata & 3.24 & 4.03 & 8.04 \\
\hline Porites lutea & 3.15 & 4.01 & \\
\hline
\end{tabular}

Scientific names are in italics.

Table 4. The average dissimilarity of the coral species of the coral communities at the surveyed sites among 2006, 2012, and 2019. Only the corals with a more than $10 \%$ cum. contribution are listed.

\begin{tabular}{|c|c|c|c|c|}
\hline & $\begin{array}{c}\text { Average } \\
\text { Abundance (2006) }\end{array}$ & $\begin{array}{c}\text { Average } \\
\text { Abundance (2012) }\end{array}$ & $\begin{array}{c}\text { Contribution } \\
(\%)\end{array}$ & $\begin{array}{l}\text { Cum. } \\
\text { Contribution (\%) }\end{array}$ \\
\hline \multicolumn{5}{|c|}{ average dissimilarity: 55.38} \\
\hline Favites russelli & 0.63 & 2.29 & 0.96 & 0.96 \\
\hline Psammocora contigua & 0.40 & 1.87 & 0.93 & 1.89 \\
\hline Astreopora ocellata & 0.76 & 2.21 & 0.89 & 2.78 \\
\hline Turbinaria irregularis & 0.00 & 1.82 & 0.89 & 3.67 \\
\hline Porites nigrescens & 0.44 & 1.78 & 0.84 & 4.50 \\
\hline Pectinia paeonia & 0.42 & 1.78 & 0.81 & 5.31 \\
\hline Hydnophora exesa & 1.03 & 1.74 & 0.78 & 6.09 \\
\hline Favites halicora & 0.66 & 2.31 & 0.77 & 6.86 \\
\hline Montipora spongodes & 0.00 & 1.60 & 0.74 & 7.60 \\
\hline Echinopora lamellosa & 1.99 & 2.33 & 0.73 & 8.33 \\
\hline Echinopora gemmacea & 1.77 & 1.47 & 0.71 & 9.04 \\
\hline \multirow[t]{2}{*}{ Goniopora columna } & 0.77 & 1.53 & 0.69 & 9.73 \\
\hline & $\begin{array}{c}\text { Average } \\
\text { Abundance (2012) }\end{array}$ & $\begin{array}{c}\text { Average } \\
\text { Abundance (2019) }\end{array}$ & $\begin{array}{c}\text { Contribute } \\
(\%)\end{array}$ & $\begin{array}{c}\text { Cum. } \\
\text { Contribute (\%) }\end{array}$ \\
\hline \multicolumn{5}{|c|}{ average dissimilarity: 55.92} \\
\hline Psammocora contigua & 1.87 & 0.36 & 0.83 & 0.83 \\
\hline Astreopora ocellata & 2.21 & 0.40 & 0.83 & 1.66 \\
\hline Gardineroseris planulata & 1.68 & 0.00 & 0.76 & 2.42 \\
\hline Favites russelli & 2.29 & 0.77 & 0.75 & 3.17 \\
\hline Favites flexuosa & 1.85 & 0.10 & 0.74 & 3.91 \\
\hline Herpolitha limax & 1.53 & 1.50 & 0.72 & 4.63 \\
\hline Pectinia paeonia & 1.78 & 0.51 & 0.71 & 5.34 \\
\hline Symphyllia agaricia & 1.68 & 0.20 & 0.69 & 6.04 \\
\hline Pavona decussata & 1.46 & 0.91 & 0.67 & 6.71 \\
\hline Lithophyllon undulatum & 1.07 & 1.45 & 0.67 & 7.38 \\
\hline Pavona venosa & 1.66 & 0.50 & 0.67 & 8.05 \\
\hline Echinopora gemmacea & 1.47 & 1.51 & 0.67 & 8.72 \\
\hline Coeloseris mayeri & 1.44 & 0.16 & 0.67 & 9.39 \\
\hline
\end{tabular}


Table 4. Cont.

\begin{tabular}{ccccc}
\hline & $\begin{array}{c}\text { Average } \\
\text { Abundance (2006) }\end{array}$ & $\begin{array}{c}\text { Average } \\
\text { Abundance (2019) }\end{array}$ & $\begin{array}{c}\text { Contribute } \\
\text { (\%) }\end{array}$ & $\begin{array}{c}\text { Cum. } \\
\text { Contribute (\%) }\end{array}$ \\
\hline average dissimilarity: 59.02 & & \\
\hline Porites nigrescens & 0.44 & 1.55 & 1.08 & 1.08 \\
Leptastrea transversa & 1.04 & 2.52 & 1.00 & 3.08 \\
Goniopora djiboutiensis & 1.96 & 0.20 & 0.95 & 3.03 \\
Acropora microphthalma & 0.89 & 1.13 & 0.93 & 4.83 \\
Favites halicora & 0.66 & 2.20 & 0.87 & 5.67 \\
Herpolitha limax & 1.16 & 1.50 & 0.84 & 6.51 \\
Fungia concinna & 0.49 & 1.45 & 0.83 & 8.31 \\
Pavona decussata & 1.30 & 0.91 & 0.81 & 8.90 \\
Montipora grisea & 1.31 & 1.95 & 0.80 & 9.68 \\
Lithophyllon undulatum & 1.26 & 1.45 & 0.79 & \\
Leptastrea pruinosa & 1.08 & 2.19 & 0.78 & \\
\hline
\end{tabular}

In terms of the variation in the functional groups of corals, various lifeforms of corals showed different tendencies in changing in abundance from 2006 to 2019 (Table 1, Figure 5). The results of the principal components analysis (PCA) revealed that a 2-D PCA was a good description of the structure, with PC1 and PC2 accounting for $78.4 \%$ and $21.6 \%$, respectively (Figure 5). The branching coral showed a massive decrease while the number of encrusting and massive corals slightly increased (Table 1; Figure 5). The same trends also occurred if we divided the DA data into outer- and inner-reefs (Figures 6 and 7).
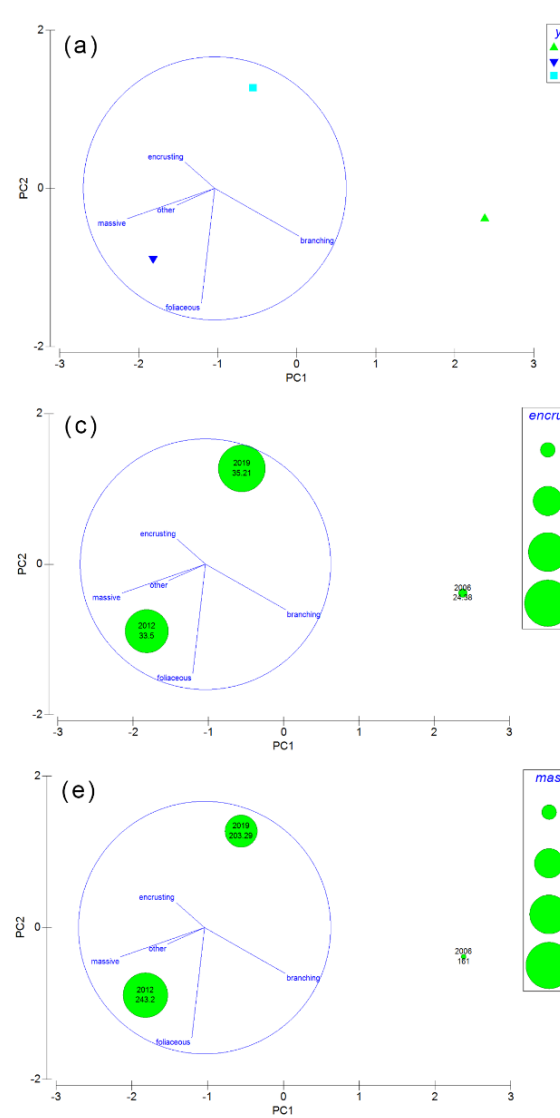

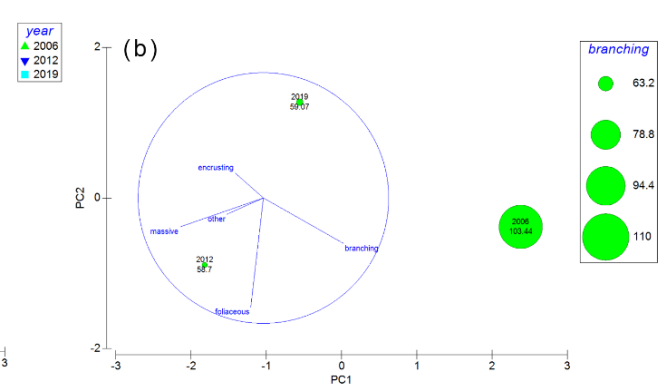

(d)
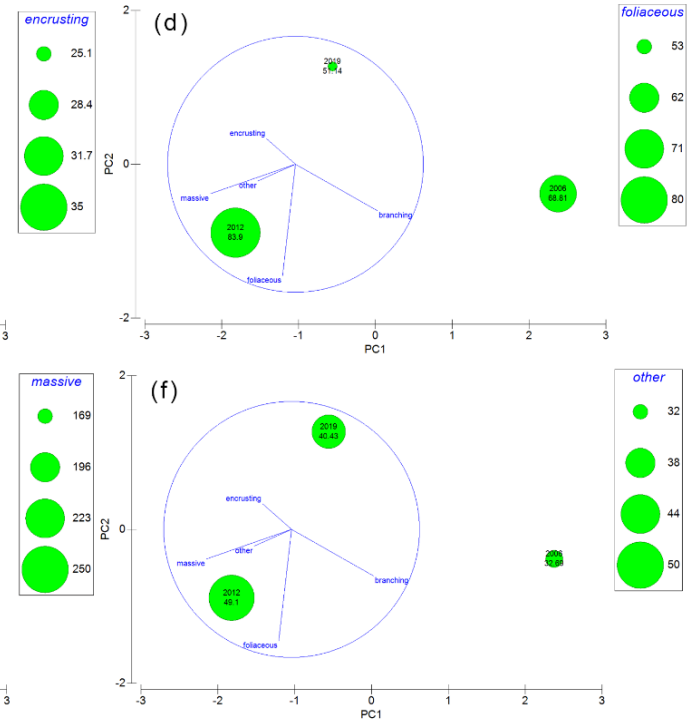

Figure 5. Principal component analysis (PCA) of the coral colonies from the Dongsha Atoll for three sampling periods (2006, 2012, and 2019): (a) hard corals; (b-f) the five functional categories of corals: branching, encrusting, foliaceous, massive, and others. PC1 accounted for $78.4 \%$ of the variability, and PC2 accounted for $21.6 \%$. The size of the green circles indicates the number of coral colonies. 

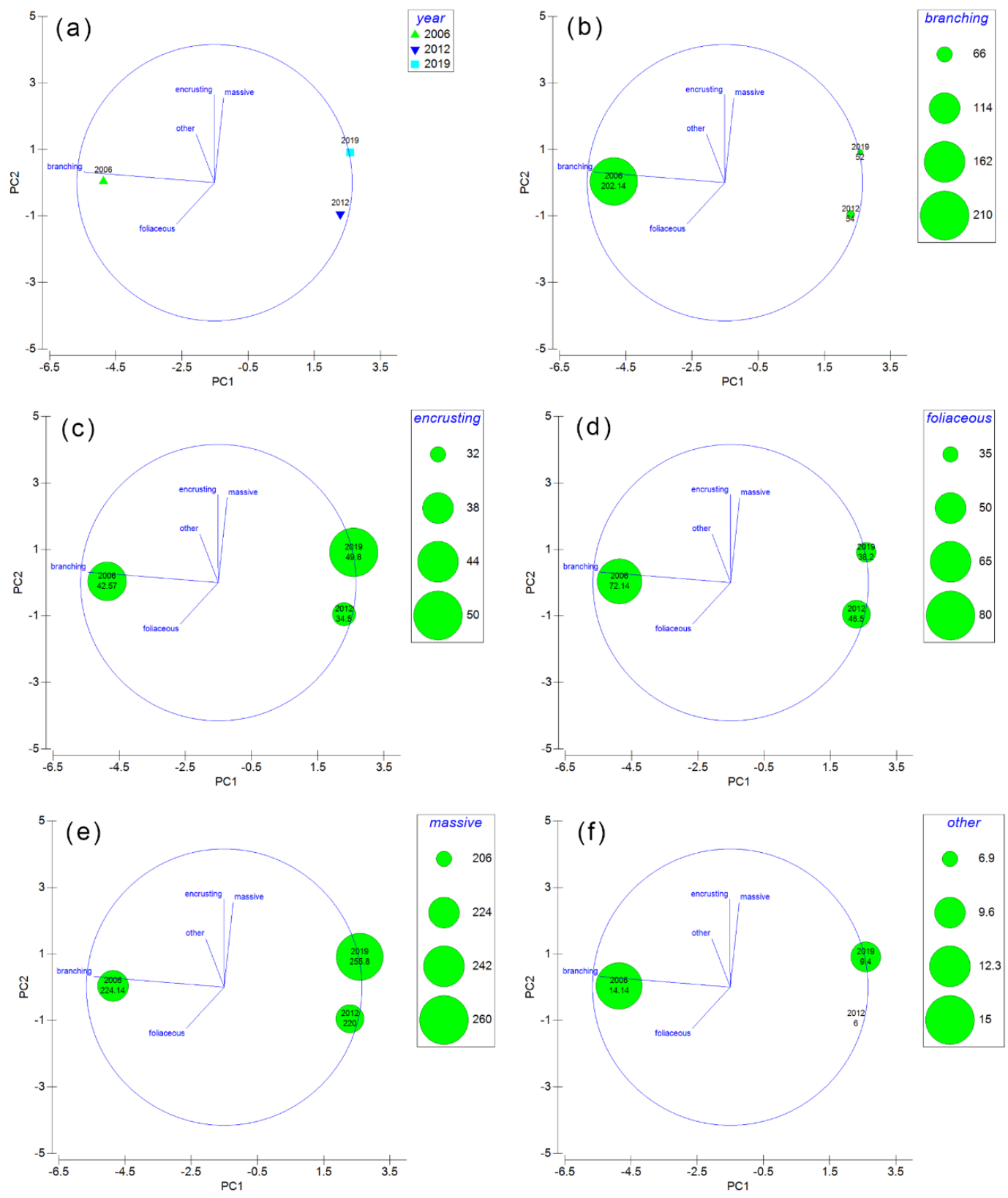

Figure 6. Principal component analysis (PCA) of the coral colonies from the outer reef of the Dongsha Atoll for three sampling periods (2006, 2012, and 2019): (a) hard corals; (b-f) the five functional categories of corals: branching, encrusting, foliaceous, massive, and others. PC1 accounted for 95.3\% of the variability, and PC2 accounted for $4.7 \%$. The size of the green circles indicates the number of coral colonies. 

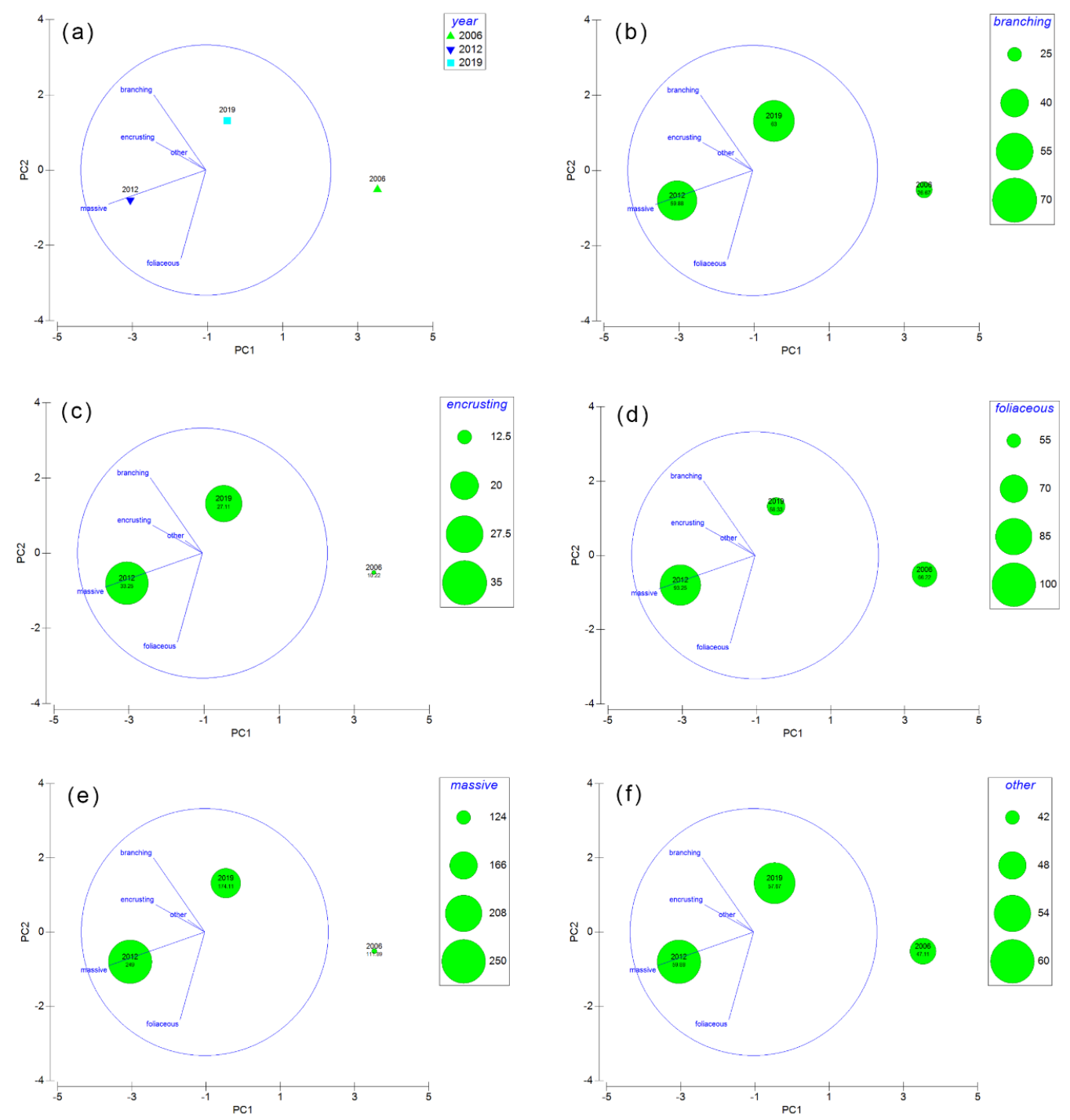

Figure 7. Principal component analysis (PCA) of the coral colonies from the inner reef of the Dongsha Atoll for three sampling periods (2006, 2012, and 2019): (a) hard corals; (b-f) the five functional categories of corals: branching, encrusting, foliaceous, massive, and others. PC1 accounted for 89.3\% of the variability, and PC2 accounted for $10.7 \%$. The size of the green circles indicates the number of coral colonies.

\section{Discussion}

Historically, the Dongsha Atoll (DA) was a well-developed reef, crossing a multi-dimensional space and with a high coral coverage. The environmental factors in the outer reef were favorable for coral growth, especially when the seawater temperature was higher [44]. Consequently, most coral species in the outer reef displayed diverse growth forms and large coral colonies. On the contrary, the coral communities in the inner reef seemed to be in an inferior condition even though some high coverages of the live corals and large coral colonies could still be found. Higher sedimentation rates, as well as the organic contents combined with greater SST fluctuations were the possible factors that restricted the distribution and development of the corals, and they might have shaped the coral communities in the inner reef [19]. When the turbidity level was high, the coral colonies were sometimes covered by heavy sedimentation, which was a common cause of some coral mortalities. The main coral species found at the sites were stress-tolerant, sediment-tolerant, or ruderal species, such as species of Poritidae, Meruliniidae, and Acroporiidae [19,20,34]. However, we found that, within only 15 years, both the outer and inner reefs have suffered from dramatic changes in live coral coverage 
(LCC), and so too the coral communities, even though it has already been protected by the Dongsha Atoll Marine National Park (DAMNP).

Coral coverage is used as an index for comparisons between different treatments as well as for temporal and spatial variations in the coral ecosystems $[35,36]$. Comparing with the results from previous studies revealed that the recurrent disturbances may contribute to coral community degradation. After the 1998 mass bleaching event, the LCC reduced to about $6 \%$ in the lagoon, 23\% in the outer reef, and then went through a stable recovery phase until 2005, in which the LCC was around $70 \%$. However, when the coral community was under significant degradation in 2006 , the species composition of the corals did not change significantly, and the dominant coral species were branching corals, such as Acropora and Pocillopora. From 2006 to 2018, the LCC never regained or exceeded the previous level. However, the LCC in 2008 and 2013 were higher than 50\% (indicating the coral communities were still in good conditions) [35,36]. From 2016 to 2019, the recovery pattern changed again (probably from 2014, but with no supporting data). In 2019, the state of the coral assemblage was at its worst $(26.23 \%$ for hard corals, $9.16 \%$ for soft corals) and the coral species composition and ecological function were thus changed due to a dramatic reduction in branching-form corals (Figures 5-7; Table 1). The Acropora was not abundant in the assemblage in 2019, and it was extirpated locally up to today (Table 1 ).

There were differences in the coral community indices among three periods in this study (Table 1). All coral community indices declined in 2019. Additionally, the coral species composition in 2019 was already changed. In total, 73 scleractinian corals were unfound in this study [45] and the dominant coral species were mainly stress-tolerant species, such as species belonging to Poritidae and Meruliniidae (Table $1 ; p<0.05$ ). In terms of the coral functional groups, the common coral growth forms were classed into five types: branching, encrusting, massive, foliaceous, and others in this study. Various coral lifeforms might have different adaptability towards physical environments and are also particularly vulnerable to a specific disturbance. Branching corals, especially Acropora and Pocillopora species, exhibit a high growth rate, but they are more susceptible to physical damages and cannot withstand the high current impact [45]. Although a few colonies of branching corals appeared in 2019 (Table 1), it is believed that the fast-growing branching corals can recolonize faster in unoccupied spaces created by disturbances. The foliaceous corals frequently appeared in the outer and inner reefs since they might have a stronger tolerance to higher seawater temperature, turbidity, and sedimentation, although they do seem to show a relatively moderate growth rate compared to branching corals (Table 1). For the slow-growing massive corals, they are usually found in the inner reefs, a more confined area with high suspended sediment loads. The massive or encrusting corals are resistant to a high seawater temperature, turbidity, sedimentation, and typhoon damages, since they possess more powerful mechanisms to remove sediment and can fight against mechanical breaks [46-50]. These stress-tolerant species are usually found as abundant in all communities, but they are only dominant in a high-stress environment where other coral lifeforms are mostly excluded [49,51,52]. On the other hand, the slow-growing massive corals have a lower spatial complexity and provide poorer fish habitat regarding supporting reef fish diversity. Recently, this has indeed become a common situation in the DA. The abundance of fishes and benthic invertebrates, especially those with commercial value, were low in most sites, suggesting that (1) the habitats were simplified; and (2) the DA was still under the threat of high fishing pressure $[19,34,39,40,45]$. The results from our SIMPER analysis also support this idea. It showed that the top six dominant species contributing to $>80 \%$ were the encrusting and massive species in 2019 , indicating the coral community was in a degraded state, and the original state or ecological function has been changed even though the DAMNP has already been established for five years (in 2012) and 12 years (in 2019).

It has been suggested that the crown-of-thorns starfish (COTS), a high sea surface temperature (SST), or coral bleaching and typhoons could serve as large-scale disturbances and thus exert considerable impact on coral reef ecosystems [46,53-55]. During the period of this study, the dramatic changes on the coral communities in the DA coincided with high seawater temperatures and typhoon 
events, suggesting that they were the vital ecological parameters for the local reef community. Coral bleaching caused by high SST has traditionally been regarded as the most important factor to affect coral distribution, growth, fecundity, mortality, and the occurrence of disease or parasites [56-59]. Typhoons also had a considerable impact on the extensive changes in the coral reefs, and the coral damages caused by the typhoon waves could be very serious [36,60-63], especially on the reefs dominated by branching and tabulate corals [64-66]. Such extensive changes in reefs might also affect fish densities and coral-associated fish assemblages [67-70]. From our field observation, the density of parrotfish at some diving sites in the DA was preserved at a high level in 2019 [45]. Our result was partially similar to Russ et al. [71], suggesting that the density of parrotfish might increase after a hard coral loss caused by typhoon or bleaching events. The crown-of-thorns starfish is a voracious predator of live coral and has been recorded several times in the DAMNP waters [29,34]. However, the COTS rarely appeared nor reached the level of a population outbreak; indeed, the first case of a COTS outbreak was only recently reported at the DA [29]. There is no doubt that many physical and biological factors have influenced the spatial and temporal variation of the DA coral reefs. Nevertheless, overfishing and destructive fishing have played a significant role in reef degradation $[19,27,34]$.

The result from a modeling study used to assess coral community persistence and resilience under different disturbance frequencies showed that shorter intervals between disturbances (every two years) would lead to a community that supported only a low level of soft coral, which the hard coral did not seem to benefit from [72]. Besides, in their report, two main points were also pointed out: (1) an eight-year disturbance frequency is suitable for coral recovery; (2) a longer interval between two disturbances (up to 16 years) may result in the monopolization of the fastest-growing corals. In the case of coral communities in the DA, we saw that the environment was no longer beneficial for hard corals due to shorter intervals between disturbances. The recurrent disturbances caused by natural disturbances and anthropogenic impacts may have a critical effect on shaping the structure and function of coral reef communities [73]. The surveys conducted from 2005 to 2019 showed that high proportions of the substrates were occupied by macroalgae, turf algae, or sediments. Algal communities would certainly undergo a rapid transition after disturbances $[60,74-77]$. The algae would not only reduce the survivability of corals but also inhibit the settlement of coral recruits and, finally, decrease the recovery potential of the coral communities $[36,74,76,78]$. From previous studies, we can see a low coral coverage and relatively high macroalgae coverage in the inner reefs, which suggests that the communities were in the process of phase-shifting from a coral-dominant to seaweed-dominant ecosystem, and this represents a low resilience ecosystem $[27,28,79]$. From our present study, we also found a dramatic change where the dominant coral type in the DA has suddenly changed from branching corals to massive or encrusting corals, within merely 5 to 10 years.

Recently, the accelerating rates of coral loss in the DA have increased the need for effective management that can improve ecosystem resilience. In the independent island reefs, local fisheries' management actions can increase the resilience of coral reef ecosystems and thus improve their recovery potential from major disturbances $[80,81]$. Limiting the algal abundance can also improve the capacity of coral reefs to remain coral-dominant [82]. In the short-term, we suggest protecting the herbivorous fish that graze on macroalgae since this may contribute to faster coral recovery [80]. Protection from fishing and reducing impacts for five years following a disturbance might also speed up the recovery rate [9]. In the long-term, an ecosystem-based management approach will be successful if the ecosystem's function and structure driving process is known and managed. In the future, more research will be needed for a more comprehensive understanding of the DA ecosystem. The recovery and dynamics of coral communities following the disturbances also need to be continually monitored. Long-term monitoring and research projects with fixed monitoring sites are essential to understand ecological changes. The marine ecosystem baseline and ecosystem valuation should be ascertained as soon as possible in order to support future management actions of the DAMNP. Moreover, adequate management or planning that is in accordance with the actual situation of the marine resources are also needed. The revision of laws and effective management have to be planned 
and discussed by governmental administrations. There are numerous things to be done: the laws need to be revised, the environmental penalties have to be raised, and the regulations need to be enforced so we can better prevent human harm to the environment. Otherwise, the DA coral reef ecosystem would be unrecoverable in the future.

Author Contributions: Conceptualization, Y.-R.C.; software, Y.-R.C. and C.-H.C.; validation, Y.-R.C., C.-H.C., D.-F.L. and C.-K.W.; formal analysis, Y.-R.C., C.-H.C., D.-F.L. and C.-K.W.; investigation, Y.-R.C.; data curation, C.-H.C., D.-F.L. and C.-K.W.; writing-original draft preparation, Y.-R.C.; writing-review and editing, Y.-R.C. and C.-H.C.; supervision, Y.-R.C.; project administration, Y.-R.C. All authors have read and agreed to the published version of the manuscript.

Funding: This research was funded by Marine National Park Headquarters, Taiwan, project number: 107406.

Acknowledgments: We deeply thank the staff of the Dongsha Atoll Marine National Park and Dongsha Atoll Research Station, Ministry of Science and Technology (MOST), Taiwan, for their supports during the study period. We also in great appreciation of the members from the Invertebrate Biology Lab, Department of Fisheries Production and Management, National Kaohsiung University of Science and Technology, for their help in carrying out field work and data analysis. We sincerely appreciate the reviewers' valuable comments and suggestions, which helped us to improve the quality of the article. We also thank Yi-Hsiang Weng and Ying-Hua Pan for the English language proofreading.

Conflicts of Interest: The authors declare no conflict of interest. The funders had no role in the design of the study; in the collection, analyses, or interpretation of data; in the writing of the manuscript, or in the decision to publish the results.

\section{Appendix A}

Table A1. Information of the survey locations conducted in 2006 (before the Dongsha Atoll Marine National Park was established), 2012 (established for 5 years), and 2019 (established for 12 years).

\begin{tabular}{|c|c|c|c|c|c|c|}
\hline $\begin{array}{l}\text { Name of } \\
\text { Locations }\end{array}$ & Sector & Date & \multicolumn{2}{|c|}{ Longitude and Latitude } & Depth & Reference \\
\hline 06-1 & outer reef & $2006 / 7 / 21$ & $20^{\circ} 35^{\prime} 10.00^{\prime \prime} \mathrm{N}$ & $116^{\circ} 47^{\prime} 50.40^{\prime \prime} \mathrm{E}$ & $10-15 \mathrm{~m}$ & Jeng 2006 [38] \\
\hline $06-2$ & outer reef & $2006 / 7 / 21$ & $20^{\circ} 35^{\prime} 23.60^{\prime \prime} \mathrm{N}$ & $116^{\circ} 49^{\prime} 22.40^{\prime \prime} \mathrm{E}$ & $10-15 \mathrm{~m}$ & Jeng 2006 [38] \\
\hline $06-3$ & outer reef & $2006 / 7 / 22$ & $20^{\circ} 46^{\prime} 51.20^{\prime \prime} \mathrm{N}$ & $116^{\circ} 48^{\prime} 28.10^{\prime \prime} \mathrm{E}$ & $11-14 \mathrm{~m}$ & Jeng 2006 [38] \\
\hline $06-4$ & outer reef & $2006 / 7 / 22$ & $20^{\circ} 46^{\prime} 48.30^{\prime \prime} \mathrm{N}$ & $116^{\circ} 51^{\prime} 40.60^{\prime \prime} \mathrm{E}$ & $10-12 \mathrm{~m}$ & Jeng 2006 [38] \\
\hline $06-5$ & outer reef & $2006 / 7 / 23$ & $20^{\circ} 42^{\prime} 58.40^{\prime \prime} \mathrm{N}$ & $116^{\circ} 42^{\prime} 14.30^{\prime \prime} \mathrm{E}$ & $12-16 \mathrm{~m}$ & Jeng 2006 [38] \\
\hline $06-6$ & inner reef & $2006 / 7 / 23$ & $20^{\circ} 42^{\prime} 09.70^{\prime \prime} \mathrm{N}$ & $116^{\circ} 52^{\prime} 02.40^{\prime \prime} \mathrm{E}$ & $13-14 \mathrm{~m}$ & Jeng 2006 [38] \\
\hline $06-7$ & inner reef & $2006 / 8 / 26$ & $20^{\circ} 42^{\prime} 12.40^{\prime \prime} \mathrm{N}$ & $116^{\circ} 48^{\prime} 17.20^{\prime \prime} \mathrm{E}$ & $5-11 \mathrm{~m}$ & Jeng 2006 [38] \\
\hline $06-8$ & inner reef & $2006 / 8 / 26$ & $20^{\circ} 39^{\prime} 56.90^{\prime \prime} \mathrm{N}$ & $116^{\circ} 47^{\prime} 57.50^{\prime \prime} \mathrm{E}$ & $14-15 \mathrm{~m}$ & Jeng 2006 [38] \\
\hline $06-9$ & outer reef & $2006 / 8 / 27$ & $20^{\circ} 40^{\prime} 29.80^{\prime \prime} \mathrm{N}$ & $116^{\circ} 55^{\prime} 25.80^{\prime \prime} \mathrm{E}$ & $10-12 \mathrm{~m}$ & Jeng 2006 [38] \\
\hline $06-10$ & outer reef & $2006 / 8 / 27$ & $20^{\circ} 44^{\prime} 31.60^{\prime \prime} \mathrm{N}$ & $116^{\circ} 54^{\prime} 46.30^{\prime \prime} \mathrm{E}$ & $12-18 \mathrm{~m}$ & Jeng 2006 [38] \\
\hline $06-11$ & inner reef & $2006 / 8 / 29$ & $20^{\circ} 41^{\prime} 54.70^{\prime \prime} \mathrm{N}$ & $116^{\circ} 46^{\prime} 51.10^{\prime \prime} \mathrm{E}$ & $17-23 \mathrm{~m}$ & Jeng 2006 [38] \\
\hline $06-12$ & inner reef & $2006 / 8 / 30$ & $20^{\circ} 41^{\prime} 42.50^{\prime \prime} \mathrm{N}$ & $116^{\circ} 44^{\prime} 46.60^{\prime \prime} \mathrm{E}$ & 4-6 m & Jeng 2006 [38] \\
\hline $06-13$ & inner reef & $2006 / 9 / 25$ & $20^{\circ} 43^{\prime} 10.50^{\prime \prime} \mathrm{N}$ & $116^{\circ} 44^{\prime} 13.30^{\prime \prime} \mathrm{E}$ & $4-5 \mathrm{~m}$ & Jeng 2006 [38] \\
\hline $06-14$ & inner reef & $2006 / 9 / 27$ & $20^{\circ} 40^{\prime} 00.80^{\prime \prime} \mathrm{N}$ & $116^{\circ} 46^{\prime} 01.10^{\prime \prime} \mathrm{E}$ & $6-8 \mathrm{~m}$ & Jeng 2006 [38] \\
\hline 06-A & inner reef & $2006 / 8 / 28$ & $20^{\circ} 42^{\prime} 48.20^{\prime \prime} \mathrm{N}$ & $116^{\circ} 42^{\prime} 20.50^{\prime \prime} \mathrm{E}$ & $3-6 \mathrm{~m}$ & Jeng 2006 [38] \\
\hline 06-B & inner reef & $2006 / 8 / 29$ & $20^{\circ} 43^{\prime} 10.50^{\prime \prime} \mathrm{N}$ & $116^{\circ} 44^{\prime} 12.70^{\prime \prime} \mathrm{E}$ & $4-6 \mathrm{~m}$ & Jeng 2006 [38] \\
\hline $12-01$ & inner reef & 2012.04 .27 & $20^{\circ} 41^{\prime} 47.73^{\prime \prime} \mathrm{N}$ & $116^{\circ} 44^{\prime} 49.32^{\prime \prime} \mathrm{E}$ & $6-11 \mathrm{~m}$ & Dai 2012 [34] \\
\hline $12-04$ & inner reef & 2012.04 .30 & $20^{\circ} 39^{\prime} 29.26^{\prime \prime} \mathrm{N}$ & $116^{\circ} 45^{\prime} 33.84^{\prime \prime} \mathrm{E}$ & $9 \mathrm{~m}$ & Dai 2012 [34] \\
\hline $12-05$ & inner reef & 2012.05 .01 & $20^{\circ} 41^{\prime} 46.07^{\prime \prime} \mathrm{N}$ & $116^{\circ} 47^{\prime} 05.24^{\prime \prime} \mathrm{E}$ & $6-12 \mathrm{~m}$ & Dai 2012 [34] \\
\hline $12-08$ & outer reef & 2012.06.08 & $20^{\circ} 46^{\prime} 47.47^{\prime \prime} \mathrm{N}$ & $116^{\circ} 48^{\prime} 25.28^{\prime \prime} \mathrm{E}$ & $7-10 \mathrm{~m}$ & Dai 2012 [34] \\
\hline $12-11$ & inner reef & 2012.07.15 & $20^{\circ} 41^{\prime} 13.20^{\prime \prime} \mathrm{N}$ & $116^{\circ} 49^{\prime} 55.61^{\prime \prime} \mathrm{E}$ & $7-13 \mathrm{~m}$ & Dai 2012 [34] \\
\hline $12-12$ & inner reef & 2012.07.16 & $20^{\circ} 43^{\prime} 16.31^{\prime \prime} \mathrm{N}$ & $116^{\circ} 44^{\prime} 09.24^{\prime \prime} \mathrm{E}$ & $4-5 \mathrm{~m}$ & Dai 2012 [34] \\
\hline $12-16$ & inner reef & 2012.09.07 & $20^{\circ} 44^{\prime} 32.69^{\prime \prime} \mathrm{N}$ & $116^{\circ} 51^{\prime} 54.38^{\prime \prime} \mathrm{E}$ & $7-10 \mathrm{~m}$ & Dai 2012 [34] \\
\hline $12-17$ & inner reef & 2012.09.09 & $20^{\circ} 38^{\prime} 30.36^{\prime \prime} \mathrm{N}$ & $116^{\circ} 49^{\prime} 30.90^{\prime \prime} \mathrm{E}$ & $8-12 \mathrm{~m}$ & Dai 2012 [34] \\
\hline $12-20$ & inner reef & 2012.09.10 & $20^{\circ} 42^{\prime} 20.35^{\prime \prime} \mathrm{N}$ & $116^{\circ} 42^{\prime} 04.82^{\prime \prime} \mathrm{E}$ & $5-6 \mathrm{~m}$ & Dai 2012 [34] \\
\hline $12-23$ & outer reef & 2012.09.12 & $20^{\circ} 38^{\prime} 24.95^{\prime \prime} \mathrm{N}$ & $116^{\circ} 42^{\prime} 00.65^{\prime \prime} \mathrm{E}$ & $14-16 \mathrm{~m}$ & Dai 2012 [34] \\
\hline
\end{tabular}


Table A1. Cont.

\begin{tabular}{ccccccc}
\hline $\begin{array}{l}\text { Name of } \\
\text { Locations }\end{array}$ & Sector & Date & \multicolumn{2}{c}{ Longitude and Latitude } & Depth & Reference \\
\hline $12-01$ & inner reef & $2019 / 8 / 31$ & $20^{\circ} 41^{\prime} 47.72^{\prime \prime} \mathrm{N}$ & $116^{\circ} 44^{\prime} 49.31^{\prime \prime} \mathrm{E}$ & $7-8.5 \mathrm{~m}$ & This study \\
$12-04$ & inner reef & $2019 / 4 / 23$ & $20^{\circ} 39^{\prime} 29.24^{\prime \prime} \mathrm{N}$ & $116^{\circ} 45^{\prime} 33.84^{\prime \prime} \mathrm{E}$ & $8-10 \mathrm{~m}$ & This study \\
$12-05$ & inner reef & $2019 / 4 / 17$ & $20^{\circ} 41^{\prime} 46.06^{\prime \prime} \mathrm{N}$ & $116^{\circ} 47^{\prime} 05.23^{\prime \prime} \mathrm{E}$ & $7-11 \mathrm{~m}$ & This study \\
$12-08$ & outer reef & $2019 / 4 / 19$ & $20^{\circ} 46^{\prime} 47.46^{\prime \prime} \mathrm{N}$ & $116^{\circ} 48^{\prime} 25.27^{\prime \prime} \mathrm{E}$ & $9-11 \mathrm{~m}$ & This study \\
$12-11$ & inner reef & $2019 / 4 / 17$ & $20^{\circ} 41^{\prime} 13.19^{\prime \prime} \mathrm{N}$ & $116^{\circ} 49^{\prime} 55.60^{\prime \prime} \mathrm{E}$ & $12-14 \mathrm{~m}$ & This study \\
$12-12$ & inner reef & $2019 / 8 / 31$ & $20^{\circ} 43^{\prime} 16.30^{\prime \prime} \mathrm{N}$ & $116^{\circ} 44^{\prime} 09.24^{\prime \prime} \mathrm{E}$ & $4-5 \mathrm{~m}$ & This study \\
$12-16$ & inner reef & $2019 / 8 / 30$ & $20^{\circ} 44^{\prime} 32.68^{\prime \prime} \mathrm{N}$ & $116^{\circ} 51^{\prime} 54.37^{\prime \prime} \mathrm{E}$ & $5-7 \mathrm{~m}$ & This study \\
$12-17$ & inner reef & $2019 / 8 / 30$ & $20^{\circ} 38^{\prime} 30.36^{\prime \prime} \mathrm{N}$ & $116^{\circ} 49^{\prime} 30.89^{\prime \prime} \mathrm{E}$ & $6.5-8.5 \mathrm{~m}$ & This study \\
$12-20$ & inner reef & $2019 / 4 / 23$ & $20^{\circ} 42^{\prime} 20.34^{\prime \prime} \mathrm{N}$ & $116^{\circ} 42^{\prime} 04.81^{\prime \prime} \mathrm{E}$ & $5-6 \mathrm{~m}$ & This study \\
$12-23$ & outer reef & $2019 / 4 / 21$ & $20^{\circ} 38^{\prime} 24.94^{\prime \prime} \mathrm{N}$ & $116^{\circ} 42^{\prime} 00.64^{\prime \prime} \mathrm{E}$ & $13-15 \mathrm{~m}$ & This study \\
$19-01$ & outer reef & $2019 / 4 / 19$ & $20^{\circ} 46^{\prime} 42.00^{\prime \prime} \mathrm{N}$ & $116^{\circ} 53^{\prime} 08.22^{\prime \prime} \mathrm{E}$ & $9-10 \mathrm{~m}$ & This study \\
$19-02$ & outer reef & $2019 / 4 / 22$ & $20^{\circ} 38^{\prime} 55.97^{\prime \prime} \mathrm{N}$ & $116^{\circ} 54^{\prime} 51.29^{\prime \prime} \mathrm{E}$ & $9.7-10.5 \mathrm{~m}$ & This study \\
$19-03$ & outer reef & $2019 / 4 / 21$ & $20^{\circ} 35^{\prime} 26.28^{\prime \prime} \mathrm{N}$ & $116^{\circ} 49^{\prime} 36.54^{\prime \prime} \mathrm{E}$ & $9-11 \mathrm{~m}$ & This study \\
$19-05$ & inner reef & $2019 / 8 / 30$ & $20^{\circ} 43^{\prime} 34.43^{\prime \prime} \mathrm{N}$ & $116^{\circ} 51^{\prime} 39.17^{\prime \prime} \mathrm{E}$ & $6-8 \mathrm{~m}$ & This study \\
\hline
\end{tabular}

\section{Appendix B}

Table A2. Information of the 11 typhoons (based on a $50 \mathrm{~km}$ radius) that passed through the Dongsha area from 2005 to 2019.

\begin{tabular}{cccccc}
\hline Number & Date & Name & $\begin{array}{c}\text { Maximum } \\
\text { Wind (knots) }\end{array}$ & Average Speed & $\begin{array}{c}\text { Min Pressure } \\
\text { (hPa) }\end{array}$ \\
\hline 1 & $2005 / 09$ & DAMREY & 80 & $14.7(\mathrm{~km} / \mathrm{h}) \mid 351(\mathrm{~km} / \mathrm{d})$ & 955 \\
2 & $2008 / 08$ & NURI & 75 & $20.7(\mathrm{~km} / \mathrm{h}) \mid 495(\mathrm{~km} / \mathrm{d})$ & 955 \\
3 & $2008 / 09$ & HAGUPIT & 90 & $23.6(\mathrm{~km} / \mathrm{h}) \mid 565(\mathrm{~km} / \mathrm{d})$ & 935 \\
4 & $2010 / 08$ & LIONROCK & 50 & $9.9(\mathrm{~km} / \mathrm{h}) \mid 238(\mathrm{~km} / \mathrm{d})$ & 985 \\
5 & $2012 / 06$ & TALIM & 50 & $15.8(\mathrm{~km} / \mathrm{h}) \mid 378(\mathrm{~km} / \mathrm{d})$ & 985 \\
6 & $2012 / 08$ & TEMBIN & 80 & $14.7(\mathrm{~km} / \mathrm{h}) \mid 353(\mathrm{~km} / \mathrm{d})$ & 950 \\
7 & $2016 / 10$ & AERE & 60 & $10.2(\mathrm{~km} / \mathrm{h}) \mid 245(\mathrm{~km} / \mathrm{d})$ & 975 \\
8 & $2016 / 10$ & HAIMA & 115 & $23.7(\mathrm{~km} / \mathrm{h}) \mid 569(\mathrm{~km} / \mathrm{d})$ & 900 \\
9 & $2018 / 09$ & MANGKHUT & 110 & $28.0(\mathrm{~km} / \mathrm{h}) \mid 671(\mathrm{~km} / \mathrm{d})$ & 905 \\
10 & $2018 / 09$ & BARIJAT & 40 & $18.0(\mathrm{~km} / \mathrm{h}) \mid 431(\mathrm{~km} / \mathrm{d})$ & 998 \\
11 & $2018 / 11$ & YUTU & 115 & $17.8(\mathrm{~km} / \mathrm{h}) \mid 427(\mathrm{~km} / \mathrm{d})$ & 900 \\
\hline
\end{tabular}

\section{References}

1. Wilkinson, C. Status of Coral Reefs of the World: 2008; Global Coral Reef Monitoring Network and Reef and Rainforest Research Centre: Townsville, Australia, 2008.

2. Hoegh-Guldberg, O. Climate change, coral bleaching and the future of the world's coral reefs. Mar. Freshw. Res. 1999, 50, 2058-2162. [CrossRef]

3. Bellwood, D.R.; Hughes, T.P.; Folke, C.; Nyström, M. Confronting the coral reef crisis. Nature 2004, 429, 827-833. [CrossRef] [PubMed]

4. Wilkinson, C. Status of Coral Reefs of the World: 2004; Australian Institute of Marine Science: Townsville, Australia, 2004.

5. Knowlton, N.; Jackson, J.B.C. Shifting baselines, local impacts, and global change on coral reefs. PLoS Biol. 2008, 6, 215-220. [CrossRef] [PubMed]

6. Hughes, T.P.; Baird, A.H.; Bellwood, D.R.; Card, M.; Connolly, S.R.; Folke, C.; Grosberg, R.; Hoegh-Guldberg, O.; Jackson, J.B.C.; Kleypas, J.; et al. Climate change, human impacts, and the resilience of coral reefs. Science 2003, 301, 929-933. [CrossRef] [PubMed]

7. Pandolfi, J.M.; Bradbury, R.H.; Sala, E.; Hughes, T.P.; Bjorndal, K.A.; Cooke, R.G.; McArdle, D.; McClenachan, L.; Newman, M.J.H.; Paredes, G.; et al. Global trajectories of the long-term decline of coral reef ecosystems. Science 2003, 301, 955-958. [CrossRef] [PubMed] 
8. Emslie, M.; Logan, M.; Williamson, D.; Ayling, A.M.; MacNeil, M.A.; Ceccarelli, D.; Cheal, A.J.; Evans, R.D.; Johns, K.A.; Jonker, M.J.; et al. Expectations and outcomes of reserve network performance following re-zoning of the Great Barrier Reef Marine Park. Curr. Biol. 2015, 25, 983-992. [CrossRef] [PubMed]

9. Mellin, C.; MacNeil, M.A.; Cheal, A.J.; Emslie, M.J.; Caley, M.J. Marine protected areas increase resilience among coral reef communities. Ecol. Lett. 2016, 19, 629-637. [CrossRef]

10. Bohnsack, J.A. Marine reserves: They enhance fisheries, reduce conflicts and protect resources. Oceanus 1993, 36, 63-71.

11. Halpern, B.S.; Warner, R.R. Marine reserves have rapid and lasting effects. Ecol. Lett. 2002, 5, 361-366. [CrossRef]

12. Halpern, B.S. The impact of marine reserves: Do reserves work and does reserve size matter? Ecol. Appl. 2003, 13, 117-137. [CrossRef]

13. Claudet, J.; Osenberg, C.W.; Benedetti-Cecchi, L.; Domenici, P.; García-Charton, J.A.; Pérez-Ruzafa, Á.; Badalamenti, F.; Bayle-Sempere, J.; Brito, A.; Bulleri, F.; et al. Marine reserves: Size and age do matter. Ecol. Lett. 2008, 11, 481-489. [CrossRef]

14. Graham, N.A.J.; Bellwood, D.R.; Cinner, J.E.; Hughes, T.P.; Norstrom, A.V.; Nystrom, M. Managing resilience to reverse phase shifts in coral reefs. Front. Ecol. Environ. 2013, 11, 541-548. [CrossRef]

15. McClanahan, T.R.; Donner, S.D.; Maynard, J.A.; MacNeil, M.A.; Graham, N.A.J.; Maina, J.; Baker, A.C.; Alemu, J.B.; Beger, M.; Campbell, S.J.; et al. Prioritizing key resilience indicators to support coral reef management in a changing climate. PLoS ONE 2012, 7, e42884. [CrossRef] [PubMed]

16. Micheli, F.; Saenz-Arroyo, A.; Greenley, A.; Vazquez, L.; Espinoza Montes, J.A.; Rossetto, M.; De Leo, G.A. Evidence that marine reserves enhance resilience to climatic impacts. PLoS ONE 2012, 7, e40832. [CrossRef]

17. Mora, C.; Sale, P. Ongoing global biodiversity loss and the need to move beyond protected areas: A review of the technical and practical shortcoming of protected areas on land and sea. Mar. Ecol. Prog. Ser. 2011, 434, 251-266. [CrossRef]

18. Selig, E.R.; Bruno, J.F. A global analysis of the effectiveness of marine protected areas in preventing coral loss. PLoS ONE 2010, 5, e9278. [CrossRef]

19. Dai, C.F. Dong-sha Atoll in the South China Sea, present and future. In Proceedings of the 10th International Coral Reef Symposium, Okinawa, Japan, 28 June-2 July 2004.

20. Chou, Y. Dongsha Atoll Research Station-A steady research platform in South China Sea. Kuroshio Sci. 2016, 10, 23-27.

21. Dai, C.F.; Fan, T.Y.; Wu, C.S. Coral fauna of Tungsha Tao (Pratas Island). Acta Oceanogr. Taiwan 1995, 34, 1-16.

22. Fang, L.S. The status of marine ecology in Dongsha Atoll. In Proceedings of the European-Asian Workshop on Investigation and Management of Mediterranean and South China Sea Coastal Zone, Hong Kong, China, 9-11 November 1998.

23. Li, J.J.; Fang, L.S. The management of Dongsha Atoll as an effective marine protected area. In Proceedings of the 4th Conference on the Protected Areas of East Asia (IUCN/WCPA/EA-4), Taipei, Taiwan, 18-23 March 2002.

24. Soong, K.; Dai, C.F.; Lee, C.P. Status of Pratas Atoll in South China Sea. In Proceedings of the 4th Conference on the Protected Areas of East Asia (IUCN/WCPA/EA-4), Taipei, Taiwan, 18-23 March 2002.

25. Li, J.J.; Lee, T.F.; Tew, K.S.; Fang, L.S. Changes in the coral community at Dongsha Atoll, South China Sea from 1975 to 1998. Acta Zool. Taiwan 2000, 11, 1-15. [CrossRef]

26. Morton, B.; Blackmore, G. South China Sea. Mar. Pollut. Bull. 2001, 42, 1236-1263. [CrossRef]

27. Morton, B. Dongsha Atoll, South China Sea: Ground Zero! Mar. Pollut. Bull. 2002, 44, 835-837. [CrossRef]

28. Nieder, C.; Liao, C.P.; Chen, C.A.; Liu, S.L. Filamentous calcareous alga provides substrate for coral-competitive macroalgae in the degraded lagoon of Dongsha Atoll, Taiwan. PLoS ONE 2019, 14, e0200864. [CrossRef] [PubMed]

29. Reimer, J.D.; Kise, H.; Wee, H.B.; Lee, C.L.; Soong, K. Crown-of-thorns starfish outbreak at oceanic Dongsha Atoll in the northern South China Sea. Mar. Biodivers. 2019, 49, 2495-2497. [CrossRef]

30. Cheng, Y.R.; Dai, C.F. Poecilostomatoid copepods associated with two widely distributed corals, Galaxea astreata (Lamarck, 1816) and Galaxea fascicularis (Linnaeus 1767), from South China Sea. Mar. Biodivers. 2018, 48, 1057-1072. [CrossRef]

31. Fang, L.S.; Shao, K.T.; Liu, L.; Li, J.J. A Survey of the Marine Ecological Resources of Dong-Sha Atoll; Fishery Management Department: Kaohsiung, Taiwan, 1990. (In Chinese) 
32. Keshavmurthy, S.; Meng, P.J.; Wang, J.T.; Kuo, C.Y.; Yang, S.Y.; Hsu, C.M.; Gan, C.H.; Dai, C.F.; Chen, C.A. Can resistant coral-Symbiodinium associations enable coral communities to survive climate change? A study of a site exposed to long-term hot water input. PeerJ 2014, 2, e327. [CrossRef] [PubMed]

33. Dai, C.F.; Qin, X.Y.; Zheng, A.Y. Coral Fauna of Dongsha Atoll in the South China Sea; Marine National Park Headquarters: Kaohsuing, Taiwan, 2013. (In Chinese)

34. Dai, C.F. Natural Resources and Management Strategy Analysis of Dongsha Atoll Natural Park; Marine National Park Headquarters: Kaohsiung, Taiwan, 2012. (In Chinese)

35. Gomez, E.D.; Alcala, A.C.; San Diego, A.C. Status of Philippine coral reefs. In Proceedings of the 4th International Coral Reef Symposium, Manila, Philippines, 18-22 May 1981.

36. Connell, J.H.; Hughes, T.P.; Wallace, C.C. A 30-year study of coral abundance, recruitment, and disturbance at several scales in space and time. Ecol. Monogr. 1997, 67, 461-488. [CrossRef]

37. Jeng, M.S. The Foundation Survey of Ecological Resources of Dongsha Atoll; Marine National Park Headquarters: Kaohsiung, Taiwan, 2005. (In Chinese)

38. Jeng, M.S. The Investigation and Monitor of Ecological Resources of Dongsha Atoll (1); Marine National Park Headquarters: Kaohsiung, Taiwan, 2006. (In Chinese)

39. Jeng, M.S. The Investigation and Monitor of Ecological Resources of Dongsha Atoll (2); Marine National Park Headquarters: Kaohsiung, Taiwan, 2008. (In Chinese)

40. Jeng, M.S. The Assessment of Ecological Status and Change Trends of Coral Reefs at Dongsha Atoll; Marine National Park Headquarters: Kaohsiung, Taiwan, 2011. (In Chinese)

41. Dai, C.F. The Study of Critical Factors for Coral Growth at Dongsha Atoll; Marine National Park Headquarters: Kaohsiung, Taiwan, 2013. (In Chinese)

42. Dai, C.F. The Investigation of Soft Corals of Dongsha Atoll Natural Park; Marine National Park Headquarters: Kaohsiung, Taiwan, 2017. (In Chinese)

43. Clarke, K.R.; Warwick, R.M. Change in Marine Communities: An Approach to Statistical Analysis and Interpretation, 2nd ed.; Primer-E: Plymouth, UK, 2001.

44. Wang, Y.H.; Dai, C.F.; Chen, Y.Y. The physical and ecological processes of internal waves on an isolated reef ecosystem in the South China Sea. Geophys. Res. Lett. 2007, 34, L18609. [CrossRef]

45. Cheng, Y.R. Natural Marine Resources Analysis of Dongsha Atoll Natural Park; Marine National Park Headquarters: Kaohsiung, Taiwan, 2019. (In Chinese)

46. Done, T.J. Phase shifts in coral reef communities and their ecological significance. Hydrobiologia 1992, 247, 121-132. [CrossRef]

47. Edinger, E.N.; Risk, M.J. Reef classification by coral morphology predicts coral reef conservation value. Biol. Conserv. 2000, 92, 1-13. [CrossRef]

48. Goh, A.H.; Sasekumar, A. The community structure of the fringing coral reef, Cape Rachado. Malay. Nat. J. 1980, 34, 25-27. [CrossRef]

49. Rogers, C.S. Responses of coral reefs and reef organisms to sedimentation. Mar. Ecol. Prog. Ser. 1990, 62, 185-202. [CrossRef]

50. Veron, J.E.N. Corals of Australia and the Indo-Pacific; Angus and Robertson: Sydney, Australia, 1986.

51. Grime, J.P. Plant Strategies and Vegetation Process; John Wiley and Sons: Chichester, UK, 1979.

52. Pastorak, R.A.; Bilyard, G.R. Effects of sewage pollution on coral reef communities. Mar. Ecol. Prog. Ser. 1985, 21, 175-189. [CrossRef]

53. Berkelmans, R.; De'ath, G.; Kininmonth, S.; Skirving, W.J. A comparison of the 1998 and 2002 coral bleaching events on the Great Barrier Reef: Spatial correlation patterns, and predictions. Coral Reefs 2004, 23, 74-83. [CrossRef]

54. Endean, R.; Cameron, A.M. Acanthaster planci population outbreaks. In Ecosystems of the World: Coral Reefs; Dubinsky, S., Ed.; Elsevier Science: New York, NY, USA, 1990.

55. Lane, D.J.W. Acanthaster planci impact on coral communities at permanent transect sites on Bruneian reefs, with a regional overview and a critique on outbreak causes. J. Mar. Biol. Assoc. UK 2012, 92, 803-809. [CrossRef]

56. Baird, A.H.; Marshall, P.A. Mortality, growth and reproduction in scleractinian corals following bleaching on the Great Barrier Reef. Mar. Biol. Annu. Rev. 2002, 237, 133-141. [CrossRef] 
57. Cheng, Y.R.; Anderson, B.M.; Meng, P.J.; Dai, C.F.; Huys, R. Copepods associated with scleractinian corals: A worldwide checklist and a case study of their impact on the reef-building coral Pocillopora damicornis (Linnaeus, 1758) (Pocilloporidae). Zootaxa 2016, 4174, 291-345. [CrossRef]

58. Douglas, A.E. Coral bleaching-how and why? Mar. Pollut. Bull. 2003, 46, 385-392. [CrossRef]

59. Harvell, C.D.; Mitchell, C.E.; Ward, J.R.; Altizer, S.; Dobson, S.P.; Ostfeld, R.S.; Samuel, M.D. Climate warming and disease risks for terrestrial and marine biota. Science 2002, 296, 2158-2162. [CrossRef]

60. Adjeroud, M.; Michonneau, F.; Edmunds, P.J.; Chancerelle, Y.; Lison de Loma, T.; Penin, L.; Thibaut, L.; Vidal-Dupiol, J.; Salvat, B.; Galzin, R. Recurrent disturbances, recovery trajectories, and resilience of coral assemblages on a South Central Pacific reef. Coral Reefs 2009, 28, 775-780. [CrossRef]

61. Fabricius, K.E.; De'ath, G.; Puotinen, M.L.; Done, T.; Cooper, T.F.; Burgess, S.C. Disturbance gradients on inshore and offshore coral reefs caused by a severe tropical cyclone. Limnol. Oceanogr. 2008, 53, 690-704. [CrossRef]

62. Gouezo, M.; Golbuu, Y.; van Woesik, R.; Rehm, L.; Koshiba, S.; Doropoulos, C. Impact of two sequential super typhoons on coral reef communities in Palau. Mar. Ecol. Prog. Ser. 2015, 540, 73-85. [CrossRef]

63. Guillemot, N.; Chabanet, P.; Le Pape, O. Cyclone effects on coral reef habitats in New Caledonia (South Pacific). Coral Reefs 2010, 29, 445-453. [CrossRef]

64. Harmelin-Vivien, M.L. The effects of storms and cyclones on coral reefs: A review. J. Coast. Res. 1994, 12, 211-231.

65. Madin, J.S.; Connolly, S.R. Ecological consequences of major hydrodynamic disturbances on coral reefs. Nature 2006, 444, 477-480. [CrossRef] [PubMed]

66. Van Woesik, R.; Ayling, A.M.; Mapstone, B. Impact of Tropical Cyclone 'Ivor' on the Great Barrier Reef, Australia. J. Coast. Res. 1991, 7, 551-557.

67. Cheal, A.; Coleman, G.; Delean, S.; Miller, I.; Osborne, K.; Sweatman, H. Responses of coral and fish assemblages to a severe but short-lived tropical cyclone on the Great Barrier Reef, Australia. Coral Reefs 2002, 21, 131-142. [CrossRef]

68. Lassig, B.R. The effects of a cyclonic storm on coral reef fish assemblages. Environ. Biol. Fishes 1983, 9, 55-63. [CrossRef]

69. Pratchett, M.S.; Munday, P.L.; Wilson, S.K.; Graham, N.A.J.; Cinner, J.E.; Bellwood, D.R.; Jones, G.P.; Polunin, N.V.C.; Mcclanaha, T.R. Effects of climate-induced coral bleaching on coral reef fishes-ecological and economics consequences. Oceanogr. Mar. Biol. Annu. Rev. 2008, 46, 251-296.

70. Wilson, S.K.; Graham, N.A.; Pratchett, M.S.; Jones, G.P.; Polunin, N.V. Multiple disturbances and the global degradation of coral reefs: Are reef fishes at risk or resilient? Glob. Chang. Biol. 2006, 12, 2220-2234. [CrossRef]

71. Russ, G.R.; Questel, S.L.A.; Rizzari, J.R.; Alcala, A.C. The parrotfish-coral relationship: Refuting the ubiquity of a prevailing paradigm. Mar. Biol. 2015, 162, 2029-2045. [CrossRef]

72. Wakeford, M.; Done, T.J.; Johnson, C.R. Decadal trends in a coral community and evidence of changed disturbance regime. Coral Reefs 2008, 27, 1-13. [CrossRef]

73. Kuo, C.Y.; Yuen, Y.S.; Meng, P.J.; Ho, P.H.; Wang, J.T.; Liu, P.J.; Chang, Y.C.; Dai, C.F.; Fan, T.Y.; Lin, H.J.; et al. Recurrent Disturbances and the Degradation of Hard Coral Communities in Taiwan. PLoS ONE 2012, 7 , e44364. [CrossRef] [PubMed]

74. Doropoulos, C.; Roff, G.; Zupan, M.; Nestor, V.; Isechal, A.L.; Mumby, P.J. Reef-scale failure of coral settlement following typhoon disturbance and macroalgal bloom in Palau, Western Pacific. Coral Reefs 2014, 33, 613-623. [CrossRef]

75. Hughes, T.P. Catastrophes, phase shifts, and largescale degradation of a Caribbean coral reef. Science 1994, 265, 1547-1551. [CrossRef]

76. Roff, G.; Chollett, I.; Doropoulos, C.; Golbuu, Y.; Steneck, R.S.; Isechal, A.L.; van Woesik, R.; Mumby, P.J. Exposure-driven macroalgal phase shift following catastrophic disturbance on coral reefs. Coral Reefs 2015, 34, 715-725. [CrossRef]

77. Russ, G.R.; McCook, L.J. Potential effects of a cyclone on benthic algal production and yield to grazers on coral reefs across the central Great Barrier Reef. J. Exp. Mar. Biol. Ecol. 1999, 235, 237-254. [CrossRef]

78. Lukoschek, V.; Cross, P.; Torda, G.; Zimmerman, R.; Willis, B.L. The importance of coral larval recruitment for the recovery of reefs impacted by Cyclone Yasi in the central Great Barrier Reef. PLoS ONE 2013, 8, e65363. [CrossRef] [PubMed] 
79. Tkachenko, K.S.; Soong, K. Dongsha Atoll: A potential thermal refuge for reef-building corals in the South China Sea. Mar. Environ. Res. 2017, 127, 112-125. [CrossRef]

80. Mumby, P.J.; Harborne, A.R. Marine reserves enhance the recovery of corals on Caribbean reefs. PLoS ONE 2010, 5, e8657. [CrossRef]

81. Steneck, R.S.; Mumby, P.J.; MacDonald, C.; Rasher, D.B.; Stoyle, G. Attenuating effects of ecosystem management on coral reefs. Sci. Adv. 2018, 4, eaao5493. [CrossRef]

82. Box, S.J.; Mumby, P.J. Effect of macroalgal competition on growth and survival of juvenile Caribbean corals. Mar. Ecol. Prog. Ser. 2007, 342, 139-149. [CrossRef]

Publisher's Note: MDPI stays neutral with regard to jurisdictional claims in published maps and institutional affiliations.

(C) 2020 by the authors. Licensee MDPI, Basel, Switzerland. This article is an open access article distributed under the terms and conditions of the Creative Commons Attribution (CC BY) license (http://creativecommons.org/licenses/by/4.0/). 